\title{
Effect of Colour of Light on Rooting Cuttings and Subsequent Growth of Chrysanthemum (Chrysanthemum $\times$ grandiflorum Ramat./Kitam.)
}

\author{
Anita Schroeter-Zakrzewska * and Faisal Anggi Pradita (D) \\ Department of Ornamental Plants, Dendrology and Pomology, Poznan University of Life Sciences, \\ Dąbrowskiego 159, 60-594 Poznań, Poland; praditaf@gmail.com \\ * Correspondence: anita.schroeter-zakrzewska@up.poznan.pl
}

check for updates

Citation: Schroeter-Zakrzewska, A.; Pradita, F.A. Effect of Colour of Light on Rooting Cuttings and Subsequent Growth of Chrysanthemum

(Chrysanthemum $\times$ grandiflorum

Ramat./Kitam.). Agriculture 2021, 11, 671. https://doi.org/10.3390/ agriculture11070671

Academic Editors:

Athanasios Koukounaras and Filippos Bantis

Received: 1 June 2021

Accepted: 8 July 2021

Published: 15 July 2021

Publisher's Note: MDPI stays neutral with regard to jurisdictional claims in published maps and institutional affiliations.

Copyright: (c) 2021 by the authors. Licensee MDPI, Basel, Switzerland. This article is an open access article distributed under the terms and conditions of the Creative Commons Attribution (CC BY) license (https:// creativecommons.org/licenses/by/ $4.0 /)$.

\begin{abstract}
A closed system for plant production with artificial light is an innovative method of plant cultivation. The objective of this study was to investigate the effect of light colour on rooting cuttings and subsequent growth of chrysanthemum (Chrysanthemum $\times$ grandiflorum Ramat./Kitam.) During the experiments, the following conditions were maintained: photoperiod $16 \mathrm{~h}$ or $10 \mathrm{~h}$, temperature $22{ }^{\circ} \mathrm{C}$, relative humidity of $65-70 \%$. LED lamps emitted the following light colours: white, blue, white + blue (50:50), and red + blue (75:25). For all light spectra, the photosynthetic photon flux density (PPFD) was $50 \mu \mathrm{mol} \mathrm{m}{ }^{-2} \mathrm{~s}^{-1}$. The effectiveness of exposure to different light colours was measured with parameters: cutting weight $(\mathrm{g})$, cutting length $(\mathrm{cm})$, length of roots, and index of leaf greenness (SPAD). The measurements referred to plant features determining plant quality, i.e., the number of flower buds and flower head, the diameter of the flower head, height of plants, index of leaf greenness (SPAD), the number of leaves, and the fresh and dry weights of aboveground parts of plants. The rooting of cuttings and subsequent growth are integral processes in the cultivation of potted chrysanthemums. Both were differently affected by the colour of light from LED lamps. The exposure to red + blue light resulted in the highest leaf greenness index (SPAD) value and the shortest cuttings with the longest roots. White + blue light significantly influenced most of the growth parameters, except the height of the plants and the number of leaves.
\end{abstract}

Keywords: light colour; LED; rooting cuttings; chrysanthemum; growth room

\section{Introduction}

Chrysanthemum is one of the most popular ornamental plants worldwide. Various methods have been used to cultivate and breed this plant in its long history. Chrysanthemum is a widely known quantitative short-day ornamental plant, which means that the length of the day and night significantly influences its growth. The plant can form flower buds in a daytime of $13.5 \mathrm{~h}$ or less. It can elongate its internodes and stem when the daytime is longer than $14 \mathrm{~h}$ under supplemental light replacing daylight. Both are necessary for different purposes. The former is for potted flowers, whereas the latter is for cut flowers [1]. Similar to other crops, chrysanthemum can normally be cultivated both indoors (in greenhouses and plastic tunnels) and outdoors (in fields). Potted chrysanthemums are usually grown indoors or in plastic tunnels and growth chambers. Ornamental plants, which strongly depend on the photoperiod, benefit from the cultivation in a plastic tunnel, where lighting, pests, diseases, watering, and harvesting are controlled. Lighting can be divided into two phases, i.e., the long-day phase and the short-day one. The aim of the former phase is to improve vegetative growth, mainly the stem length and width, and to increase the number of leaves. Plants are exposed to light for more than $12 \mathrm{~h}$ per day for 10-25 days. The aim of the latter phase is to promote generative growth, such as the formation of flower buds for the anthesis period. Plants are exposed to light less than $12 \mathrm{~h}$ per day for 6-11 weeks [2]. 
Fast propagation techniques are necessary to meet the market demand and produce plants for different purposes. Cutting is a simple and low-cost propagation method. Practically, it can be applied at the onset of the vegetative or reproductive phase [3]. Apart from that, common cutting methods have several advantages: simplicity, the general uniformity of results, faster root formation (even by applying auxin), and higher income. The economic reason tends to dominate mainly due to the increasing demand for cut and potted chrysanthemums worldwide [4]. Several factors may influence successful cutting propagation. These are: the application of phytohormone (auxin), the substrate for cuttings, stem parts cut, nutritional status, and light requirements. Light is crucial for plants, including short-day ones such as chrysanthemum [5]. Light, which is necessary for photosynthesis, has the characteristics of both a particle and a wave. The optimum light wavelength for photosynthesis is $400-700 \mathrm{~nm}$. However, outside that range, the plants still sphotosynthesise at a low rate [6,7]. According to Zhen and Bugbee [8], far-red photons (701-750 nm) are abundant in sunlight but are considered inactive for photosynthesis and are thus excluded from the definition of photosynthetically active radiation (PAR; $400-700 \mathrm{~nm}$ ). The consistent response among diverse species indicates that the mechanism is common in higher plants. These results suggest that far-red photons $(701-750 \mathrm{~nm}$ ) should be included in the definition of PAR.

A specific wavelength represents the colours of light affecting physiological processes, which are responsible for the plant's growth from the vegetative to the generative phase. For instance, the interaction of far-red (FR) and blue (B) light in a specific red (R): far-red (FR) spectrum increases the photosynthetic rate of chrysanthemum plants because chlorophyll can intensely absorb blue light (about $430 \mathrm{~nm}$ ) and far-red light (about $660 \mathrm{~nm}$ ). Both can enhance the electron excitation level during photosynthesis, activate some enzymes to catalyse reactions on the electron chain, and soptimise photosystem activities [9].

Studies on potted chrysanthemums cultivated in growth chambers showed that light affected the growth and flowering of the plants. Different colours of light may have different influences on the chrysanthemum flowering time. Zalewska et al. [10] report that the cultivar Baja from the Sombrero group of chrysanthemums was grown under short-day conditions and exposed to artificial blue light and daylight, which constituted the control. The blue light caused the plants to flower earlier than in the case of daylight. Jerzy et al. [11] observed that the source of light, such as a fluorescent lamp or LED lamp, had different effects on the duration of cultivation. Moreover, the intensity of light can manipulate some morphological features of plants, such as flower development and leaf elongation. The cultivation in growth chambers was found to have a better influence on the post-harvest quality of potted chrysanthemums. As light is a limiting factor, specific colours and wavelengths of light can be used for various purposes. Blue and white light can accelerate flowering, so both are suitable to meet market demands quickly. Red light delays flowering, so it can be applied to plants in storage rooms to keep them longer for later production [11].

The increasing demand for plant-based products such as fruit, flowers, and chemical substances caused the need to enhance plant growth and flowering by light supplementation. The use of light-emitting diode (LED) lamps positively affected protected cultivation in growth chambers, plastic tunnels, and greenhouses. At the same wavelength, the LED lamp produces lesser heat than a fluorescent lamp by different heat dissipation mechanisms, so it can save a higher amount of energy, and it is more eco-friendly. It is also beneficial for plants because it promotes germination, soptimises the photosynthetic rate, triggers stomatal conductance, creates plant compactness, extends roots and shoots, promotes flowering, and enhances fruit taste. These effects heavily depend on the plant species as well as the colour and wavelength of the light generated by LED lamps, which may either positively or negatively affect plant growth [12].

Kozai [13] observed that although there are numerous advantages of the use of LED lamps in agriculture, they are not applied in conventional farming in developing countries. On the contrary, developed countries such as Japan started using LED lamps 
in urban agriculture in 2010. This idea was implemented due to the limited number of fields for cultivation and insufficient sun exposure. LED lamps were applied to solve these problems. This trend also increases the use of LEDs in urban agriculture because they meet all requirements for high effectiveness (only specific spectra are used), safety, and healthy production. LED characteristics surpass the characteristics of other unused wavelengths and have low irradiance. They generate low amounts of heat, which is environmentally friendly.

Light is also important for plants to build biomass and activate the genes responsible for the activation of phytochromes. Several light colours can interact with cryptochromes and phototropins. Blue light affects stomatal conductance and thus increases photosynthesis. Potted chrysanthemums cultivated under $100 \%$ blue light had longer shoots than the plants grown under white light with shade avoidance response. Moreover, higher intensity of blue light can significantly affect rhizogenesis during adventitious root formation, which may be manifested by an increase in the dry root mass and the number of adventitious roots [9].

However, blue light may inversely affect root development in some species cultivated in vitro. For instance, Moon et al. [14] observed that birch pine and tsuru-rindo (Triptospermum japonicum) grown in blue light were scharacterised by low chlorophyll content, a small number of roots, and short internodal length and plant height.

Akbarian et al. [15] found that blue LEDs increased the emergence of seedlings and root length of Zinnia and Impatiens during the germination period. Furthermore, LEDs can make some ornamental plants (gerbera, marigold, petunia, and zinnia) sturdier than others, which were not illuminated with an LED lamp [16].

A closed plant production system with artificial light is an innovative plant cultivation method. The aim of the study was to assess the effect of different colours of light on the rooting of chrysanthemum (Chrysanthemum $\times$ grandiflorum Ramat./Kitam) cv. 'Nova Lime' cuttings and their subsequent growth in a room with no access to sunlight.

\section{Materials and Methods}

\subsection{Plant Material}

A total of 120 cuttings of medium-flowered pot chrysanthemum (Chrysanthemum $\times$ grandiflorum Ramat./Kitam.) cv. 'Nova Lime' were placed in a controlled environment growth room in a three-layer shelf system) on $120 \times 50 \mathrm{~cm}$ shelves lined with felt (Figure 1). The shelves were equipped with a LED Tube (LeuchTek, Ahrensburg, Germany). The lamps emitted light of different colours, i.e., white (cool white- $5000 \mathrm{~K})$, blue $(460 \mathrm{~nm})$, and as well as combinations of two colours: blue + white (50:50) $(400-500 \mathrm{~nm})$, and red + blue (75:25) (460-660 nm). The cuttings were rooted for 2 weeks. They were regularly sprayed with water in order to maintain high humidity. The experiment was completed when most of the cuttings formed roots. During the rooting, the day length was $16 \mathrm{~h}$.

Next, the rooted cuttings were replanted into pots $\left(1 \mathrm{dm}^{3}\right)(5$ cuttings per pot) with commercial peat substrate TS1 ( $\mathrm{pH}$ 6.0). Then, the plants were placed in the same growth room and irradiated with the same light condition with the LED lamps. For 2 weeks, the rooted cuttings were grown in the growth room, where they were illuminated for $16 \mathrm{~h}$ a day (from 6 a.m. to 10 p.m.) and pinched off above the fifth leaf. After 7 days, the pinched off parts were sprayed with a retardant daminozide at concentration of $2550 \mathrm{mg} \cdot \mathrm{dm}^{-3}$. Then, they were illuminated for $10 \mathrm{~h}$ (from 6 a.m. to 4 p.m.) for around 3 months to promote flower opening. They were watered every second day.

For different spectra of LED light, the photosynthetic photon flux density (PPFD) was $50 \mu \mathrm{mol} \mathrm{m}{ }^{-2} \mathrm{~s}^{-1}$ and was measured by means of Optel phytophotometer FR- 10 (Sonopan, Białystok, Poland). The lighting system was placed at $50 \mathrm{~cm}$ distances over the plant in order to adjust the photosynthetic photon flux density (PPFD) to the same value for all treatments. 


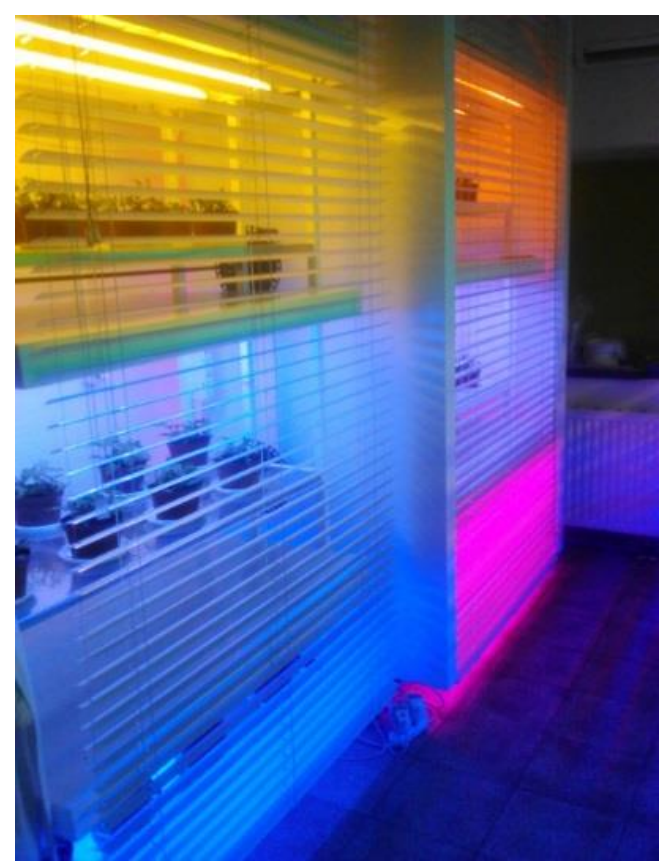

Figure 1. Three-layer shelf system in growth room.

The air temperature in the growth room was maintained at $20{ }^{\circ} \mathrm{C}$, and the relative humidity was $65-70 \%$. The light spectrum characteristics measured with a spectroradiometer (USB 4000, Ocean Optics Inc., Dunedin, FL, USA) is shown in Figures 2-5.

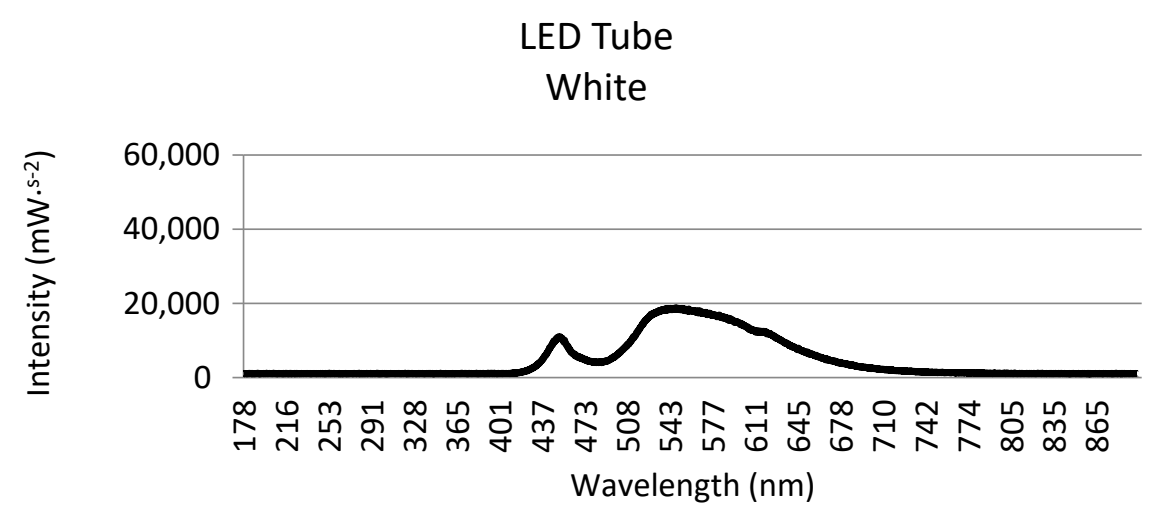

Figure 2. Spectral characteristic of white light.

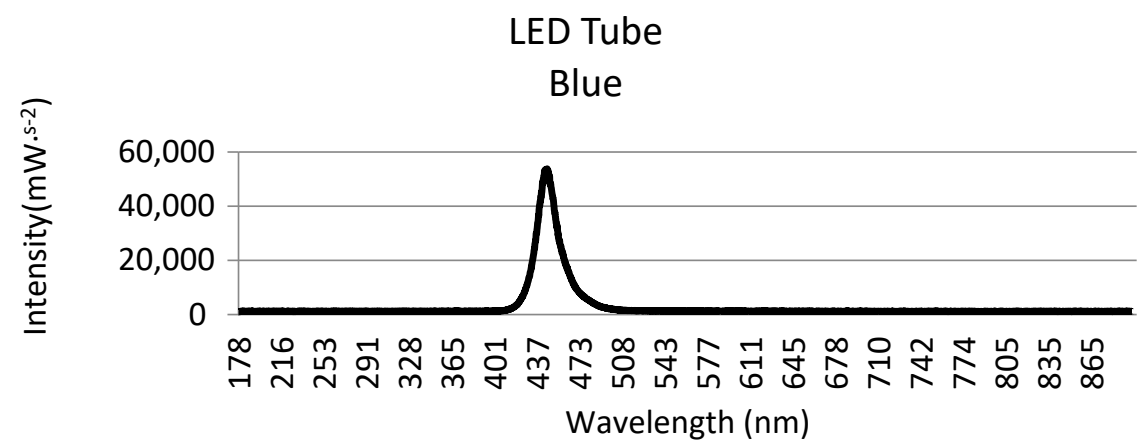

Figure 3. Spectral characteristic of blue light. 


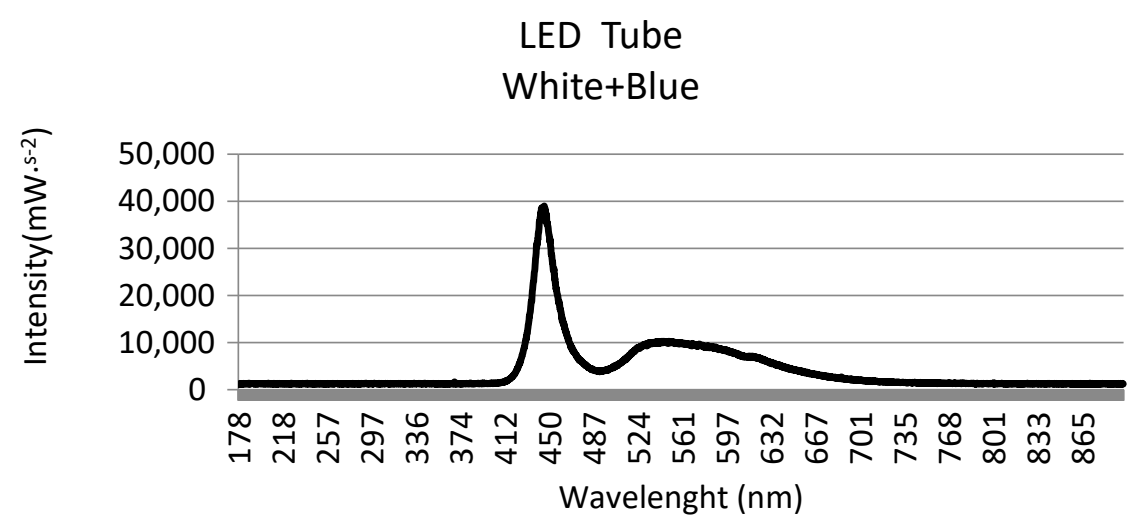

Figure 4. Spectral characteristic of white + blue light.

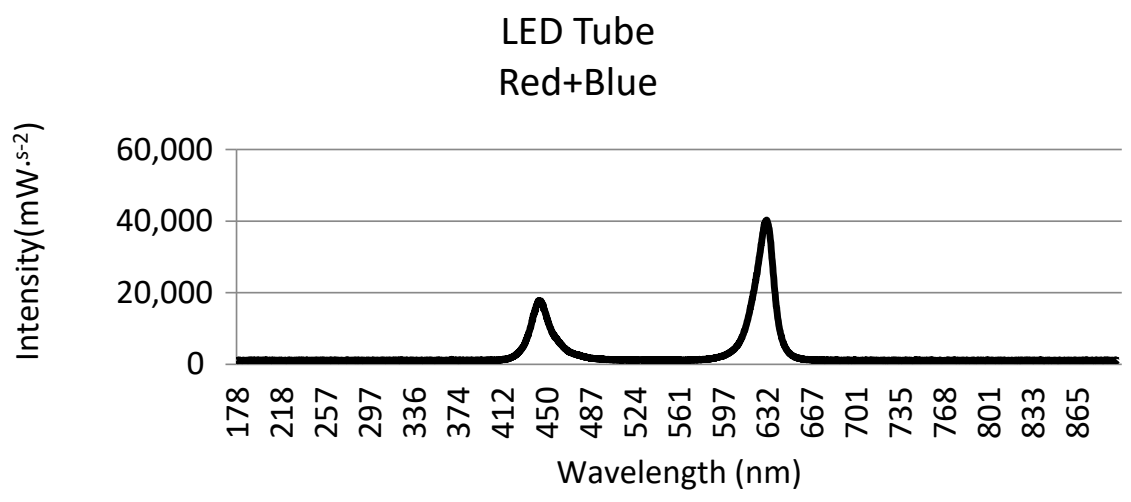

Figure 5. Spectral characteristic of red + blue light.

\subsection{Experimental Design}

The experiment was conducted in a completely srandomised design, where the exposure of the plants to different light colours was analysed, i.e., white light (W), blue light (B), red + blue light $(\mathrm{RB})$, and white + blue light (WB). Rooted chrysanthemum cuttings were set in 4 treatments with 6 pots in each. There were 5 cuttings in each pot. The experiment was conducted at the Marcelin Experimental Station of the Faculty of Agricultural, Horticultural and Bioengineering Poznań University of Life Sciences, Poland, between July and November 2020.

The following morphological traits of the plants were measured: the number of flower buds and flower heads, the diameter of the flower heads, the height of the plants, the number of leaves, the fresh and dry weights of aboveground parts of plants. After the biometric measurements, the plants were dried in a drier $48 \mathrm{~h}$ at $60^{\circ} \mathrm{C}$.

The leaf greenness index (SPAD) was measured with an N-Tester apparatus (Yara International ASA, Norway). This measurement is used to determine the intensity of green colour in leaves and consists of the determination of the light absorption coefficient connected with the presence of chlorophyll at a wavelength of $650 \mathrm{~nm}$ and absorption by the leaf tissue at a wavelength of $940 \mathrm{~nm}$.

\subsection{Statistical Analysis}

The results were analysed statistically with one-way analysis of variance and Duncan's multiple range test at a significance level of $\alpha=0.05$. 


\section{Results}

\subsection{Cuttings Rooting}

The experiment showed that the rooting of the cuttings was influenced by the light colour (Table 1). The parameters were measured before or at the beginning of the rooting process and 2 weeks later, after the cuttings rooted optimally. The exposure of the chrysanthemum cuttings to blue and white lights significantly increased their weight, i.e., from 0.7 and $0.8 \mathrm{~g}$ to 3.0 and $2.9 \mathrm{~g}$, respectively. On the other hand, the cuttings exposed to white + blue and red + blue light combinations had the same average weight of $2.7 \mathrm{~g}$.

Table 1. The effect of light colour to rooting cuttings of chrysanthemum.

\begin{tabular}{cccccccc}
\hline & \multicolumn{3}{c}{ Before Rooted Cuttings } & \multicolumn{2}{c}{ After 2 Weeks Rooting Process } \\
\cline { 2 - 8 } Colour of Light & $\begin{array}{c}\text { Weight of } \\
\text { Cutting } \\
(\mathbf{g})\end{array}$ & $\begin{array}{c}\text { Length of } \\
\text { Cutting } \\
\mathbf{( c m )}\end{array}$ & $\begin{array}{c}\text { Index of } \\
\text { Greening Leaves } \\
\text { (SPAD) }\end{array}$ & $\begin{array}{c}\text { Weight of } \\
\text { Cutting } \\
(\mathbf{g})\end{array}$ & $\begin{array}{c}\text { Length of } \\
\text { Cutting } \\
(\mathbf{c m})\end{array}$ & $\begin{array}{c}\text { Index of } \\
\text { Greening Leaves } \\
\text { (SPAD) }\end{array}$ & $\begin{array}{c}\text { Length of } \\
\text { Roots } \\
\text { (cm) }\end{array}$ \\
\hline White & $0.8 \mathrm{a} *$ & $7.0 \mathrm{a}$ & $35.2 \mathrm{a}$ & $2.9 \mathrm{~b}$ & $9.1 \mathrm{~b}$ & $44.4 \mathrm{~b}$ & $8.9 \mathrm{a}$ \\
Blue & $0.7 \mathrm{a}$ & $7.5 \mathrm{a}$ & $37.1 \mathrm{a}$ & $3.0 \mathrm{~b}$ & $9.7 \mathrm{~b}$ & $40.4 \mathrm{a}$ & $11.0 \mathrm{~b}$ \\
White + Blue & $0.7 \mathrm{a}$ & $7.2 \mathrm{a}$ & $36.2 \mathrm{a}$ & $2.7 \mathrm{a}$ & $9.8 \mathrm{~b}$ & $47.0 \mathrm{c}$ & $11.2 \mathrm{~b}$ \\
Red + Blue & $0.8 \mathrm{a}$ & $7.4 \mathrm{a}$ & $36.7 \mathrm{a}$ & $2.7 \mathrm{a}$ & $8.7 \mathrm{a}$ & $51.6 \mathrm{~d}$ & $13.1 \mathrm{c}$ \\
\hline
\end{tabular}

${ }^{*}$ Means followed by the same letters are not significantly different at $\alpha=0.05$.

The length of the cuttings exposed to white, white + blue, and blue lights increased considerably and amounted to $9.1,9.7$, and $9.8 \mathrm{~cm}$, respectively. Regardless of the length of individual cuttings, the exposure to light increased their length by about $2.1-2.6 \mathrm{~cm}$. The smallest increase in the length of the chrysanthemum cuttings was observed under red + blue light $-1.7 \mathrm{~cm}$, approximately from 7.4 to $8.7 \mathrm{~cm}$.

The statistical analysis showed that the colour of light also influenced the leaf greenness index (SPAD). Three of the light treatments increased the index after 2 weeks of rooting. The highest SPAD values (51.0) were noted for the cuttings grown under red + blue light. The other two treatments increased the index value as follows: white light -44.4 and white + blue light-47.0.

Regardless of the three main parameters, the chrysanthemum cuttings successfully formed numerous roots of different sizes and lengths to absorb nutrients and water. Therefore, the length of the roots was measured from the base of the main shoot to the main root apex. As shown in Table 1, the chrysanthemum plants developed the longest roots (average length -about $13.1 \mathrm{~cm}$ ) under red + blue light. The exposure to white + blue and blue lights resulted in shorter roots, i.e., 11.2 and $11.0 \mathrm{~cm}$, respectively. The chrysanthemum cuttings grown under white light had the shortest roots, i.e., $8.9 \mathrm{~cm}$.

\subsection{Subsequent Growth of Rooting Cutting}

After the rooting of the cuttings, the chrysanthemum plants were transferred into pots (diameter $14 \mathrm{~cm}$ ) in order to observe their subsequent growth under different colours of light from the LED lamps. Eight parameters were measured at the end of the generative period: the height of the plants, the number of flowers, the flower diameter, the number of flower buds, the leaf greenness index, the number of leaves, and fresh and dry weights. The results showed that the colour of light significantly affected the morphological traits of the chrysanthemums.

The plants exposed to white and red + blue lights grew shorter. By contrast, the tallest plants were produced under blue light. They were on average $17-41 \%$ taller than the other plants (Table 2). 
Table 2. The effect of light colour on vegetative features of chrysanthemum.

\begin{tabular}{cccccc}
\hline Colour of Light & $\begin{array}{c}\text { Height of Plants } \\
(\mathbf{c m})\end{array}$ & $\begin{array}{c}\text { Index of Greening Leaves } \\
\text { (SPAD) }\end{array}$ & $\begin{array}{c}\text { Number of } \\
\text { Leaves }\end{array}$ & $\begin{array}{c}\text { Fresh Weight of } \\
\text { Above-Ground } \\
\text { Parts of Plants } \\
(\mathbf{g})\end{array}$ & $\begin{array}{c}\text { Dry Weight of } \\
\text { Above-Ground } \\
\text { Parts of Plants } \\
(\mathbf{g})\end{array}$ \\
\hline White & $9.2 \mathrm{a} *$ & $57.4 \mathrm{~b}$ & $242.6 \mathrm{a}$ & $52.2 \mathrm{~b}$ & $28.9 \mathrm{~b}$ \\
Blue & $15.4 \mathrm{c}$ & $55.5 \mathrm{~b}$ & $265.1 \mathrm{a}$ & $52.4 \mathrm{~b}$ & $32.3 \mathrm{c}$ \\
White + Blue & $12.7 \mathrm{~b}$ & $65.9 \mathrm{c}$ & $281.3 \mathrm{a}$ & $65.2 \mathrm{c}$ & $38.1 \mathrm{~d}$ \\
Red + Blue & $10.6 \mathrm{a}$ & $52.8 \mathrm{a}$ & $366.0 \mathrm{~b}$ & $46.9 \mathrm{a}$ & $26.3 \mathrm{a}$ \\
\hline
\end{tabular}

${ }^{*}$ Means followed by the same letters are not significantly different at $\alpha=0.05$.

Regardless of the average number of leaves in one pot per treatment, during the subsequent growth, the rooted cuttings produced the most leaves under red + blue light, i.e., about 366 leaves. The plants exposed to the other lights produced about 84-123 fewer leaves than those cultivated under red + blue light.

The colour of light significantly influenced the leaf greenness index. The leaves of the plants exposed to white + blue light were darker than the other leaves-their SPAD value was 65.9. Conversely, the plants grown under red + blue light had the lowest SPAD values (52.8). The SPAD values of the plants grown under white and blue lights were 57.4 and 55 , respectively.

The chrysanthemum plants exposed to white + blue light had the highest fresh and dry weights, i.e., about 65.2 and $38.1 \mathrm{~g}$ on average. The plants exposed to white and blue lights did not differ significantly in the fresh weight. Their average fresh weights were 52.2 and $52.4 \mathrm{~g}$, respectively. The plants exposed to red + blue light had the lowest fresh (46.9 g) and dry (26.3 g) weights.

Interestingly, only the chrysanthemum plants cultivated under white + blue light had almost two times more flowers - about five flowers / pot. The other treatments resulted in similar numbers of flowers-not more than three flowers/pot (Table 3).

Table 3. The effect of light colour on generative feature of chrysanthemum.

\begin{tabular}{cccc}
\hline Colour of Light & $\begin{array}{c}\text { Number of Flower } \\
\text { Heads }\end{array}$ & $\begin{array}{c}\text { Flower Head Diameter } \\
(\mathbf{c m})\end{array}$ & $\begin{array}{c}\text { Number of Flower } \\
\text { Buds }\end{array}$ \\
\hline White & $2.6 \mathrm{a}^{*}$ & $4.4 \mathrm{a}$ & $9.8 \mathrm{a}$ \\
Blue & $2.8 \mathrm{a}$ & $6.2 \mathrm{~b}$ & $15.8 \mathrm{c}$ \\
White + Blue & $5.0 \mathrm{~b}$ & $6.9 \mathrm{~b}$ & $17.3 \mathrm{~d}$ \\
Red + Blue & $2.3 \mathrm{a}$ & $4.2 \mathrm{a}$ & $11.1 \mathrm{~b}$ \\
\hline
\end{tabular}

${ }^{*}$ Means followed by the same letters are not significantly different at $\alpha=0.05$.

The flower diameter also depended significantly on the light colour. White and red + blue lights noticeably inhibited the growth of flowers. The plants grown under blue and white + blue lights developed the largest flowers.

The statistical analysis showed that the colour of light also influenced the number of flower buds. The plants produced the most flowers and buds under white + blue light. On the other hand, the plants developed the fewest flowers and buds under white light-2.4 flowers and 7.5 buds on average.

\section{Discussion}

\subsection{Rooted Cutting Activity}

Root formation, which is affected by several factors, is a crucial point for the survival of cuttings. The number of adventitious roots formed during rhizogenesis determines plants' abilities to absorb soil nutrients. Being short-day plants, chrysanthemum cuttings can form adventitious roots when stimulated by light and hormone activities. Light is a major factor responsible for the expression of genes resulting in phytohormone and phytochrome activity. Light promotes or inhibits the growth pattern of chrysanthemum 
cuttings depending on its wavelength, irradiance, and colour [17]. In our experiment, the colour of light affected the formation of roots and subsequent growth of chrysanthemums.

Two weeks of observation of root development in the cuttings showed that the colours of light differently affected the weight and length of the cuttings, their leaf greenness index (SPAD), and root length. Red + blue light (RB) accelerated the growth of rooted cuttings and induced the greenness of leaves but resulted in the low fresh weight of the cuttings. An earlier study on cherry rootstock microcuttings of the Colt cultivar showed that exposure to dichromatic blue and red light caused a remarkable increase in the root length. Root elongation was related to the phytochrome photoequilibrium value and photoreceptors. Blue and red light interacted strongly and regulated elongation activities more intensely than a single light colour. This effect was caused by the fact that red light stimulated root elongation more intensely than far-red and blue light and thus compensated for the blue light root elongation deficiency [18]. The exposure of chrysanthemum cuttings to dichromatic red + blue light with the same PPFD ratio $\left(30: 30 \mu \mathrm{mol} \mathrm{m}^{-2} \mathrm{~s}^{-1}\right)$ gave similar results. After 3 weeks, the cuttings exposed to red + blue light had the highest percentage of developed root [6].

On the contrary, the exposure of Jatropha curcas rooted cuttings to red + blue light generated by LED lamps (50:50 photon flux density) inhibited root formation, as opposed to blue, red, and white lights [19]. Kurilcik et al. [20] observed that blue light added to red and far-red light affected the rhizogenesis of chrysanthemum microcuttings. The blue light component was found to inhibit the rooting rate, but it increased the ratio of the fresh and dry weight of the explants due to the interaction between cryptochromes and phytochromes. Both of them affected the development of adventitious roots, but the influence of phytochromes was more pronounced. Phytochromes also regulate phytohormones such as auxin. However, this scheme requires further investigations, as plants respond differently to each photon flux density of the light colour. The growth of plants may be differently affected by the colour of light.

Matysiak [21] observed that the combination of light characteristics did not always result in optimal rooting percentage. The exposure of roses of the 'Konstancin' cultivar to dichromatic white + blue light resulted in a lower rooting percentage than the exposure to the monochromatic white light of high photosynthetic photon flux density (PPFD) $100 \mu \mathrm{mol} \mathrm{m}{ }^{-2} \mathrm{~s}^{-1}$. The dichromatic light did not increase the fresh weight of the cuttings (roots and shoots) and the length of shoots significantly. The rooting of rose cuttings was induced by high irradiance and delayed by the blue light component during the exposure. These findings were consistent with the results of our experiment, in which the cuttings rooted under blue light were characterised by an intermediate increase in weight and length.

As Table 1 shows, the chrysanthemum cuttings in our experiment poorly responded to the exposure to monochromatic lights, i.e., white and blue lights, as expressed by the length of roots, cuttings, and the leaf greenness index (SPAD), except the weight of the cuttings. Baque and Hahn [22] observed a moderate effect of blue light on the length of roots of Morinda citrifolia leaf microcuttings grown in vitro. However, the root growth under red and blue lights were faster than under red + blue light. The fresh weight of the cuttings was also positively affected by monochromatic light. A lower amount of $\mathrm{H}_{2} \mathrm{O}_{2}$ applied under blue LEDs accelerated root formation triggered by rapid cell division.

This was caused by blue light slightly induced the activity of the genes expressing superoxide dismutase (SOD), and subsequently activated ascorbate peroxidase (APX) and catalase (CAT) mRNA to function at the same time in order to metabolically convert toxic $\mathrm{H}_{2} \mathrm{O}_{2}$ into $\mathrm{H}_{2} \mathrm{O}$. The lower amount of $\mathrm{H}_{2} \mathrm{O}_{2}$ and higher amount of $\mathrm{H}_{2} \mathrm{O}$ promoted cell elasticity. Further, the elasticity triggered a division of cells. As a result, the root cells divided rapidly because there was a low level of toxic free radicals.

The illumination with white LEDs had a less significant effect on the root length, but in comparison with the other light treatments, it slightly increased the weight, length, and greenness index of the cuttings. The research on the sensitivity of rooting behaviour 
of Wiekstromia gemmate microcuttings showed that specific light wavelengths and other qualities were reflected by various growth patterns. Consequently, the plants grown under white LED lamps had shorter roots than those grown under warm white fluorescent lamps and subsequently, they had epinastic and greener leaves. Further investigations showed that that other light spectral could not support auxin transport basipetally, so the endogenous auxin level may be high in the apical zone but low in the root elongation zone [23].

The rooted cuttings exposed to blue light had the lowest leaf greenness index (SPAD) value after 2 weeks. The second-lowest leaf greenness index (SPAD) value was noted after the white-light treatment. Interestingly, both of the light treatments positively affected the leaf greenness index. This result was consistent with the findings of the experiments conducted by Zheng and Van Labeke [24] and Schroeter-Zakrzewska et al. [25]. The researchers observed that the blue light component caused the shaded leaf effect, so physically, the leaves were darker than under the other treatments.

\subsection{Subsequent Growth of Rooted Cuttings}

The successful transferring of rooted chrysanthemum cuttings to their subsequent growth was determined by light characteristics such as the type of light and its colour. Nonetheless, some light colours had little or no effect on the vegetative and generative growth of potted chrysanthemums. Blue light combined with white and red lights considerably increased the height of chrysanthemums of the Covington cultivar. Monochromatic blue light had a moderate influence on the plant height [25]. Our experiment showed that the plants exposed to blue light had different characteristics. They were taller than the other plants. However, there were similar results of an earlier study on plants exposed to white + blue light. The plants grew optimally under exposure to blue light. The other treatments did not noticeably enhance the height of the plants.

The next vegetative parameter, i.e., the number of leaves, was related to the plant height. As light spectra enabled the manipulation of the chrysanthemum shoot architecture, they caused the shade avoidance syndrome. The cuttings grown only in the growth chamber with exposure to red and blue light were characterised by numerous bud outgrowths and the shortest height. Due to low apical dominance, these plants were short and compact. The application of red light either as a single light source or its combination with other light spectra [26]. Similar to earlier studies, our experiment also showed that the exposure to blue and red lights resulted in the shortest and most compact plants with numerous axillary vegetative buds. The buds then formed numerous thick and small leaves.

The quality of ornamental plants is also determined by leaf colour. It was shown in the experiments that the light colour significantly affected the SPAD index value. It increased after the exposure to white + blue light as well as white and blue lights, but it did not increase after the exposure to red + blue light. This finding was similar to the results of the study on lettuce conducted by Kleiber et al. [27]. The SPAD index value of the lettuce cultivated under white + blue light was lower than that of the lettuce grown under blue light.

The LED lamps emitting white + blue light resulted in more flower buds, flowers, and subsequently in greater flower diameters than the exposure to blue light, which resulted in the highest SPAD index value. The higher leaf greenness index (SPAD) value was positively correlated with the photosynthetic rate and thus affected the generative stage. Nissim-Levi et al. [28], Schroeter-Zakrzewska et al. [25], and Jerzy et al. [11] made similar observations for LED lamps emitting monochromatic blue light, which triggered rapid flower bud development. The induction of blue light itself depended strongly on the duration of exposure. Partch and Sancar [29] found that the blue light component activated cryptochromes so that they controlled flowering photoperiodically. The cryptochrome activity pathways were complex due to the interaction between auxin biosynthesis and light regulation [30]. 
On the other hand, Kaiser et al. [31] studied tomato plants and found that the combination of red + blue light induced the development of flower buds and increased the yield and biomass more than single blue light. This effect may have been caused by the plants' different responses to the light spectra, which depended not only on physiological activities but also on the cellular and gene levels. Further investigations on other crops are necessary for this field to find appropriate artificial or supplemental light treatments.

In order to analyse the correlation between light colour induction and each growth stage of chrysanthemums, the fresh and dry weight of the aboveground parts of plants were measured at the end of the experiment. The strongest correlation was observed between the high SPAD index value caused by the illumination with white + blue light and the fresh and dry weights of the aboveground parts of plants.The favourable effect of the white and blue light onto the fresh and dry weights in Scarlet sage was reported by SchroeterZakrzewska [32]. In the conducted experiment, the plants exposed to red + blue light were characterised by the lowest fresh and dry weights. They obtained different results reported by Heo et al. [33] in African marigold and Scarlet sage which were characterised by higher dry weight when the plants were cultivating under red- and blue- coloured lights.

\section{Conclusions}

The aim of the study was to assess the effect of different colours of light on the rooting of chrysanthemums (Chrysanthemum $\times$ grandiflorum Ramat./Kitam) cv. 'Nova Lime' cuttings and their subsequent growth in a growth room with no access to sunlight. During this experiment, morphological characteristics were measured. The cuttings rooted under white and blue lights were heavier than those exposed to white + blue and red + blue light combinations. The cuttings rooted under red + blue light were the shortest. The exposure to red + blue light resulted in the highest index of greening leaves (SPAD) value and the shortest cuttings with longest roots. White + blue light significantly influenced most of the growth parameters of chrysanthemum plants, except the height of the plants and the number of leaves. The blue light treatment optimally affected the plant height. Red + blue light emitted by the LED lamps had a significant influence on the number of leaves.

A closed system for plant production with artificial light is an innovative method of plant cultivation. The growing trend of closed cultivation system is still applied in vegetable crops widely and in ornamental crops; in turn, it had already been started a few years ago. Thus, more information about this area is needed for farmers of ornamental plants. The conducted experiment proved that good quality chrysanthemum could be obtained at a low light intensity, which can significantly reduce energy costs. Lower electrical energy costs can increase profits.

Author Contributions: Conceptualisation, A.S.-Z.; methodology, A.S.-Z.; software, A.S.-Z. and F.A.P.; validation, A.S.-Z. and F.A.P.; formal analysis, A.S.-Z. and F.A.P.; investigation, A.S.-Z. and F.A.P.; resources, F.A.P. and A.S.-Z.; data curation, A.S.-Z. and F.A.P.; writing-original draft preparation, F.A.P. and A.S.-Z.; writing-review and editing, A.S.-Z. and F.A.P.; visualisation, A.S.-Z. and F.A.P.; supervision, A.S.-Z.; project administration, A.S.-Z. and F.A.P.; funding acquisition, A.S.-Z. and F.A.P. All authors have read and agreed to the published version of the manuscript.

Funding: The APC was co-funded within the framework of the Ministry of Science and Higher Education program 'Regional Initiative Excellence' in years 2019-2022, (No.005/RID/2018/19), financing amount 1,200,000 PLN.

Institutional Review Board Statement: Not applicable.

Informed Consent Statement: Not applicable.

Data Availability Statement: Not applicable.

Acknowledgments: Authors thank the horticultural farm A.A. Kłak in Poznań, for donating cuttings.

Conflicts of Interest: The authors declare no conflict of interest. The funders had no role in the design of the study; in the collection, analyses, or interpretation of data; in the writing of the manuscript, or in the decision to publish the results. 


\section{References}

1. Sung, J.W.; Sander, W.H.; Wim, V.L. Responses of supplemental blue light on flowering and stem extension growth of cut chrysanthemum. Sci. Hortic. 2014, 165, 69-74.

2. Ploeg, A.V.D.; Heuvelink, E. The influence of temperature on growth and development of chrysanthemum cultivars: A review. J. Hortic. Sci. Biotechnol. 2006, 81, 174-182. [CrossRef]

3. De Vier, C.L.; Geneve, R.L. Flowering influences adventitious root formation in chrysanthemum cuttings. Sci. Hortic. 1997, 70, 309-318. [CrossRef]

4. Blythe, E.K.; Sibley, J.L.; Tilt, K.M.; Reuter, J.M. Methods of auxin application in cutting propagation: A review of 70 years of scientific discovery and commercial practice. J. Environ. Hortic. 2007, 25, 166-185. [CrossRef]

5. Thakur, T.; Grewal, H.S. Influence of photoperiodic night interruption on sustainable potted flower production of chrysanthemum cv. Snowball. Int. J. Curr. Microbiol. Appl. Sci. 2018, 72, 1282-1287. [CrossRef]

6. Taiz, L.; Zeiger, E. Plant Physiology, 3rd ed.; Sinauer Associates: Sunderland, UK, 2002; pp. 111-143.

7. McCree, K. Test of current definitions of photosynthetically active radiation against leaf photosynthesis data. Agric. Meteorol. 1972, 10, 443-453. [CrossRef]

8. Zhen, S.; Bugbee, B. Far-red photons have equivalent efficiency to traditional photosynthetic photons: Implications for re-defining photosynthetically active radiation. Plant Cell Environ. 2020, 43, 1259-1272. [CrossRef]

9. Christiaens, A.; Gobin, B.; Huylenbroeck, J.V.; Labeke, M.V. Adventitious rooting of Chrysanthemum is stimulated by a low red: Far-red ration. J. Plant Physiol. 2019, 236, 117-123. [CrossRef] [PubMed]

10. Zalewska, M.; Wożny, A.; Piszczek, P. Effect of blue light on the flowering of Dendranthema grandiflora Tzvelev Sambrero group. Zesz. Probl. Postępu Nauk. Rolniczych. 2002, 483, 305-310. (In Polish)

11. Jerzy, M.; Zakrzewski, P.; Schroeter-Zakrzewska, A. Effect of colour light on the opening of inflorescence buds and post-harvest longevity of pot chrysanthemums (Chrysanthemum x grandiflorum (Ramat.) Kitam). Acta Agrobot. 2011, 64, 13-18. [CrossRef]

12. Ouzounis, T.; Rosenqvist, T.E.; Ottosen, C.O. Spectral effects of artificial light on plant physiology and secondary metabolism: A review. HortScience 2015, 50, 1128-1135. [CrossRef]

13. Kozai, T. Why LED Lighting for Urban Agriculture? In LED Lighting for Urban Agriculture; Kozai, T., Fujiwara, K., Runkle, E.S., Eds.; Springer Science + Business Media Singapore: Singapore, 2016; pp. 3-18.

14. Moon, H.K.; Park, S.Y.; Kim, Y.W.; Kim, C.S. Growth of tsuru-rindo (Triptospermum japonicum) cultured in-vitro under various sources of light-emitting diode (LED) irradiation. J. Plant Biol. 2006, 49, 1-6. [CrossRef]

15. Akbarian, B.; Maltoobi, M.; Mahna, N. Effects of LED light on seed emergence and seedling quality of four bedding flowers. J. Ornam. Plants 2016, 6, 115-123.

16. Craver, J.K.; Boldt, J.K.; Lopez, R.G. Comparison of supplemental lighting provided by high-pressure sodium lamps or lightemitting diodes for the propagation and finishing of bedding plants in a commercial greenhouse. HortScience 2019, 54, 52-59. [CrossRef]

17. Gill, C.S.; Jung, H.Y.; Lee, C.; Eom, S.H. Blue light and NAA treatment significantly improve rooting on single leaf-bud cutting of chrysanthemum via upregulated rooting-related genes. Sci. Hortic. 2020, 274, 1-9. [CrossRef]

18. Lacona, M.; Muleo, R. Light quality affects in vitro adventitious rooting and ex vitro performance of cherry rootstock colt. Sci. Hortic. 2010, 125, 630-636. [CrossRef]

19. Daud, N.; Faizal, A.; Geelen, D. Adventitious rooting of Jatropha curcas L. is stimulated by phlorogucinol and by red LED light. In Vitro Cell. Dev. Biol. Plant 2013, 49, 183-190. [CrossRef]

20. Kurilcik, A.; Miklusyte-Canova, R.; Dapkuniene, S.; Zilinskaite, S.; Kurilcik, G.; Tamulaitis, G.; Duchovskis, P.; Zukauskas, A. In vitro culture of chrysanthemum plantlets using light-emitting diodes. Cent. Eur. J. Biol. 2008, 3, 161-167. [CrossRef]

21. Matysiak, B. Vertical production of Konstancin rose cuttings in the growth chamber under LED light. J. Hortic. Res. 2020, 28, 29-34. [CrossRef]

22. Baque, M.A.; Hahn, E.J. Induction mechanism of adventitious root from leaf explants of Morinda citrifolia as affected by auxin and light quality. In Vitro Cell. Dev. Biol. Plant 2010, 46, 71-80. [CrossRef]

23. Verstraeten, I.; Buyle, H.; Werbrouck, S.; Van Labeke, M.C.; Geelen, D. In Vitro shoot growth and adventitious rooting of Wiekstromia gemmata depends on light quality. Isr. J. Plant Sci. 2020, 67, 16-26. [CrossRef]

24. Zheng, L.; Van Labeke, M.C. Effects of different irradiation levels of light qualities on chrysanthemum. Sci. Hortic. 2018, 233, 124-131. [CrossRef]

25. Schroeter-Zakrzewska, A.; Kleiber, T.; Zakrzewski, P. The response of chrysanthemum (Chrysanthemum x grandiflorum Ramat./Kitam) cv Covington to a different range of fluorescent and led light. J. Elem. 2017, 22, 1015-1026. [CrossRef]

26. Dierck, R.; Dhooghe, E.; Huylenbroeck, J.V.; Straeten, D.V.D.; Keyser, E.D. Light quality regulates plant architecture in different genotypes of Chrysanthemum morifolium Ramat. Sci. Hortic. 2017, 218, 177-186. [CrossRef]

27. Kleiber, T.; Borowiak, K.; Schroeter-Zakrzewska, A.; Budka, A.; Osiecki, S. Effect of ozone treatment and light colour on photosynthesis and yield of lettuce. Sci. Hortic. 2017, 217, 130-136. [CrossRef]

28. Nissim-Levi, A.; Kitron, M.; Nishri, Y.; Ovaida, R.; Forer, I.; Shamir, M.O. Effects of blue and red LED lights on growth and flowering of Chrysanthemum morifolium. Sci. Hortic. 2019, 254, 77-83. [CrossRef]

29. Partch, C.L.; Sancar, A. Invited review-photochemistry and photobiology of chryptochrome blue light photopigments: The search for a photocycle. Photochem. Photobiol. 2005, 81, 1291-1304. [CrossRef] 
30. Halliday, K.J.; Garcia, J.F.M.; Josse, E.M. Integration of light and auxin signaling. Cold Spring Harb. Perspect. Biol. 2009, 1, 1-11. [CrossRef]

31. Kaiser, E.; Ouzounis, T.; Giday, H.; Schipper, R.; Heuvelink, E.; Marcelis, L.F.M. Adding blue to red supplemental light increases biomass and yield of greenhouse-grown tomatoes, but only to an optimum. Front. Plant Sci. 2019, 9, 1-11. [CrossRef]

32. Schroeter-Zakrzewska, A. Influence of the light colour on the seedling quality of French marigold and Scarlet sage. Bulg. J. Agric. Sci. 2015, 21, 951-956.

33. Heo, J.; Lee, C.; Chakrabarty, D.; Paek, K. Growth responses of marigold and salvia bedding plants as affected by monochromic or mixture radiation provided by a Light Emitting Diode (LED). Plant Growth Regul. 2002, 38, 225-230. [CrossRef] 